\title{
Thermal Conductivity of Thin Walled Compacted Graphite Iron Castings
}

\author{
Marcin GORNY, ${ }^{1) *}$ Janusz LELITO, ${ }^{2)}$ Magdalena KAWALEC ${ }^{1)}$ and Gabriela SIKORA ${ }^{11}$ \\ 1) Department of Engineering of Cast Alloys and Composites, Faculty of Foundry Engineering, AGH University of Science and \\ Technology, Reymonta 23, Krakow, 30-059 Poland. $\quad 2$ 2) Department of Foundry Processes Engineering, Faculty of \\ Foundry Engineering, AGH University of Science and Technology, Reymonta 23, Krakow, 30-059 Poland.
}

(Received on April 28, 2015; accepted on June 3, 2015)

\begin{abstract}
This study addresses the effect of the cooling rate and of titanium additions on the exhibited microstructure and thermophysical parameters of thin-walled compacted graphite iron (TWCI) castings as determined by changing the moulding materials (silica sand and insulating sand LDASC), and Ferro Titanium. The research was conducted for thin-walled iron castings with a 3-mm wall thickness. The tested material represents the occurrence of graphite in the shape of nodules, flakes ( $C$ and D types, according to ISO Standard) and compacted graphite with a different shape factor and percent of nodularity. Thermal conductivity has been evaluated by the laser flash technique in a temperature range of $22-600^{\circ} \mathrm{C}$. The results show that the cooling rates together with the titanium content largely influence the microstructure, graphite morphology and finally thermal conductivity of thin walled castings. Finally mechanism for thermal conductivity profile as a function of temperature for thin wall castings with different graphite morphology is provided.
\end{abstract}

KEY WORDS: compacted graphite iron castings; thermal conductivity; thermal diffusivity; specific heat; graphite morphology.

\section{Introduction}

Recently the need to save energy and resources has forced designers and constructor to focus on light weight castings. Customarily, this has led to the increased use of light alloys and composites. ${ }^{1-4)}$ From an economical and ecological point of view, thin walled castings made of ductile or compacted graphite cast iron can compete in terms of mechanical, foundry and thermophysical properties with light alloys and composites. ${ }^{5-7)}$

Compacted Graphite Iron (CGI) also known as Vermicular Graphite Iron is a modern engineering alloy with attractive features that enable its use in the automotive industry. Good thermophysical properties of CGI are of high importance, especially in thin wall castings which are simultaneously, thermally and mechanically loaded, such as cylinder blocks, heads and brake systems. ${ }^{8-11)}$

Thermophysical properties of thin walled compacted graphite iron castings are strongly influenced by a graphite fraction, its morphology, eutectic grains, and metallic matrix. ${ }^{12-16)}$ A ferrite metallic matrix has a higher thermal conductivity than a pearlitic one. The thermal conductivity of graphite is strongly anisotropic and along hexagonal planes, the conductivity is very high. At room temperature, thermal conductivity of graphite can be as high as 500 $\mathrm{W} /(\mathrm{m} \cdot \mathrm{K}) .{ }^{12)}$ In the case of white cast iron, the carbon pres-

\footnotetext{
* Corresponding author: E-mail: mgorny@agh.edu.pl DOI: http://dx.doi.org/10.2355/isijinternational.ISIJINT-2015-234
}

ent in the form of cementite reduces thermal conductivity (about $8 \mathrm{~W} /(\mathrm{m} \cdot \mathrm{K})$ ).

Compacted graphite cast iron may have a complex microstructure, especially in a thin sections. This is due to the fact that the process of obtaining thin-walled castings is not simple, because it is associated with a wide range of cooling rates at the beginning of graphite eutectic solidification. ${ }^{17,18)}$ With increasing cooling rates in thin-walled CGI castings, thermal undercooling increases and graphite gradually becomes nodular, resulting in an increased nodule count and lower compact graphite ratio. Therefore, the production of thin-walled compacted iron castings is more difficult than that of thicker section iron. ${ }^{19)}$ The formation of compacted graphite in thin wall castings is thus a very difficult process with only a narrow margin of residual $\mathrm{Mg}$ : too much $\mathrm{Mg}$ will give an excess of nodules, whereas too little $\mathrm{Mg}$ will lead to the formation of gray iron flake structures. ${ }^{20)}$ Therefore, a typical compacted graphite cast iron has a mixed structure with $5 \%-30 \%$ of the graphite has a spheroidal structure. The presence of flake graphite, which has the biggest impact on thermophysical properties, is unacceptable. Surface-active chemical elements (oxygen, sulfur) in the liquid metal significantly affects the morphology of crystallizing graphite and thus on cast iron thermal and mechanical properties. These surface-active chemical elements may also be in the mould and these create the conditions for a degenerated graphite zone near the surface layer of cast iron, which is characterized by different properties relative to the base material. ${ }^{21,22)}$ The graphite degradation in the surface 
Table 1. Results of chemical composition

\begin{tabular}{|c|c|c|c|c|c|c|c|c|c|c|c|}
\hline \multicolumn{12}{|c|}{ Chemical composition (wt.\%) } \\
\hline Alloy & $\mathrm{C}$ & $\mathrm{Si}$ & $\mathrm{Mn}$ & $\mathrm{P}$ & $\mathrm{S}$ & $\mathrm{Cr}$ & $\mathrm{Ni}$ & $\mathrm{Cu}$ & $\mathrm{Al}$ & $\mathrm{Ti}$ & $\mathrm{Mg}$ \\
\hline I & 3.63 & 2.47 & 0.03 & 0.026 & 0.017 & 0.03 & 0.00 & 0.050 & 0.010 & 0.009 & 0.010 \\
\hline II & 3.66 & 2.55 & 0.04 & 0.027 & 0.020 & 0.03 & 0.01 & 0.040 & 0.010 & 0.070 & 0.005 \\
\hline III & 3.60 & 2.57 & 0.05 & 0.023 & 0.018 & 0.04 & 0.040 & 0.060 & 0.021 & 0.133 & 0.021 \\
\hline IV & 3.60 & 2.57 & 0.05 & 0.023 & 0.018 & 0.04 & 0.040 & 0.060 & 0.021 & 0.133 & 0.021 \\
\hline V & 3.62 & 2.43 & 0.04 & 0.030 & 0.014 & 0.02 & 0.030 & 0.010 & 0.020 & 0.008 & 0.014 \\
\hline VI & 3.62 & 2.43 & 0.04 & 0.030 & 0.014 & 0.02 & 0.030 & 0.010 & 0.020 & 0.008 & 0.014 \\
\hline VII & 3.60 & 2.58 & 0.06 & 0.028 & 0.022 & 0.03 & 0.030 & 0.010 & 0.011 & 0.009 & 0.013 \\
\hline
\end{tabular}

layer is the most critical for thin wall castings, where it could become more than $10 \%$ of the total section. It affects also castings of thicker walls, due to the long solidification time providing an extended metal/mould interaction time.

The literature provides limited data $^{23)}$ on the relation of high cooling rate, structure and thermophysical properties of thin wall compacted graphite cast iron. In this work we consider the occurrence of graphite in the shape of nodules, flakes (types C and D) and compacted graphite with a different shape factor and percent of nodularity relative to the thermal conductivity at ambient and elevated temperatures in thin wall castings with a wall thickness of $3 \mathrm{~mm}$.

\section{Experimental}

\subsection{Preparation of Material}

The experimental melts were produced in an electrical induction furnace of intermediate frequency with a $15 \mathrm{~kg}$ capacity crucible. The furnace charge consisted of Sorelmetal, technically pure silica, Fe-Mn, and steel scrap. Melting was carried out at $1490^{\circ} \mathrm{C}$, with the liquid metal held at this temperature for $2 \mathrm{~min}$. This was followed by vermicularization and inoculation operations using the bell method. For the vermicularization process $\mathrm{Fe}-\mathrm{Si}-\mathrm{Mg}(6 \%$ $\mathrm{Mg}$ ), as well as Fe-Ti (alloys II-IV) were used to obtain differential titanium concentrations. The Fe-Si alloy $(75 \%$ $\mathrm{Si}, 0.75-1.25 \% \mathrm{Ca}, 0.75-1.25 \% \mathrm{Ba}, 0.75-1.25 \% \mathrm{Al}$ ) in an amount of 0.6 wt. $\%$ was used for inoculation. The chemical composition of the investigated iron is given in Table 1. The pouring temperature was approximately $1400^{\circ} \mathrm{C}$. Experimental castings applied in investigations were test blocks, according to the ASTM A 536-84 Standard, with plate section sizes of $g=3 \mathrm{~mm}$ at the bottom end (Fig. 1). The sand molds (alloys I, II, III, VI) were made using conventional green moulding sand consisting of silica sand, bentonite $(7$ wt.\%), a water:bentonite ratio of 0.4 and a granularity of 100-200 $\mu \mathrm{m}$.

In addition, sand moulds (alloys IV, V, VII) were made using Low-Density Alumina-Silicate Ceramic (LDASC, composition $25-45 \% \mathrm{Al}_{2} \mathrm{O}_{3}$ and $55-75 \% \mathrm{SiO}_{2}$ ) whose heat transfer properties are drastically reduced (approx. by 4 fold) when compared with those of silica sands. Moreover, the sand is characterized by a low density $0.35-0.45 \mathrm{~g} / \mathrm{cm}^{3}$. The moulds were equipped with Pt/PtRh10 thermocouples of $0.1 \mathrm{~mm}$ diameter and with their tips located in the geometrical centre of each mould cavity. An Agilent 34970A

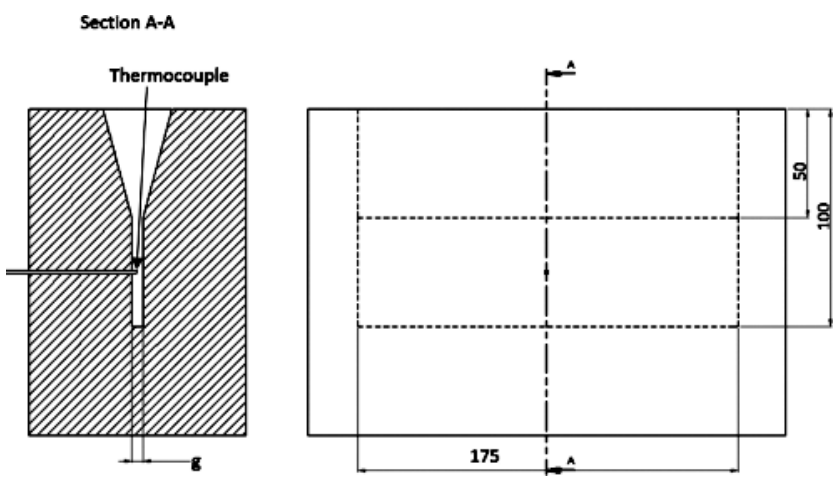

Fig. 1. Scheme of the test block casting.

electronic module was employed for temperature recording.

\subsection{Structure Characterization}

A metallographic characterization was made using a Leica MEF 4M microscope and a QWin v3.5 quantitative analyzer at various magnifications in order to determine the graphite and matrix morphologies. At least five areas in the central part of the sample were used for these measurements. In addition, the samples were examined by a JEOL JSM-550LV scanning electron microscope (SEM) operated at $20 \mathrm{kV}$.

\subsection{Thermal Conductivity Measurement}

Plate shaped samples (alloys from I to VII, Table 1) were cut out from the centre of the bottom part of each casting. The specimens for thermophysical parameters measurements had dimensions of $10 \times 10 \times 2 \mathrm{~mm}$. Test were assessed at a room temperature of $22^{\circ} \mathrm{C}$ rising to approximately $600^{\circ} \mathrm{C}$, at intervals of $100^{\circ} \mathrm{C}$. At each temperature three measurements for statistical purposes were carried out.

The thermal conductivity was calculated by using the obtained data together with a bulk density and specific heat:

$$
k(T)=\lambda(T) \cdot c_{\mathrm{P}}(T) \cdot \rho(T)
$$

where: $\lambda(\mathrm{T})$-thermal diffusivity $\left(\mathrm{m}^{2} / \mathrm{s}\right) ; c_{\mathrm{p}}(\mathrm{T})$-specific heat $(\mathrm{J} /(\mathrm{kg} \cdot \mathrm{K})) ; \rho(\mathrm{T})$-material density $\left(\mathrm{kg} / \mathrm{m}^{3}\right)$.

The thermal diffusivity of cast iron samples was measured using a LFA 427 device using the pulsar laser method (Laser Flash Analysis). The measurement was carried out in a pure argon atmosphere to prevent oxidation. The thermal diffusivity values were determined using the Cape- 
Lehmann + pulse correction model with a standard variation of less than $2 \%$.

The specific heat of the samples was determined using the comparative method with the use of the pulsar laser having a reference-Inconel 600 sample (with a known coefficient of thermal expansion). The specific heat value was determined using the following formula:

$$
c_{p}^{\text {sample }}=\frac{T_{\infty}^{\text {ref }}}{T_{\infty}^{\text {sample }}} \cdot \frac{Q^{\text {sample }}}{Q^{\text {ref }}} \cdot \frac{V^{\text {sample }}}{V^{\text {ref }}} \frac{\rho^{\text {ref }} \cdot D^{\text {ref }}}{\rho^{\text {sample }} \cdot D^{\text {sample }}} \cdot \frac{d_{\text {hole }}^{2, \text { sample }}}{d_{\text {hole }}^{2, \text { ref }}} \cdot c_{p}^{\text {ref }}
$$

where: $c_{\mathrm{p}}$-specific heat of sample/reference $(\mathrm{J} /(\mathrm{kg} \cdot \mathrm{K}))$; $T$-temperature of sample/reference $(\mathrm{K}) ; Q$-energy absorbed by sample/reference $(\mathrm{J}) ; V$-amplitude of signal amplification of sample/reference; $\rho$-density of the sample/reference $\left(\mathrm{kg} / \mathrm{m}^{3}\right) ; D$-thickness of the material $(\mathrm{m}) ; d$-diameter of measurement sample/reference (m).

Materials density in a tested temperature range (22$600^{\circ} \mathrm{C}$ ) were determined with DIL $402 \mathrm{C}$ Netzsch dilatometer. The measurements were carried out at a scanning rate of $5 \mathrm{~K} / \mathrm{min}$ within this temperature range.

\section{Results and Discussion}

\subsection{Thermal Analysis}

The cooling curves obtained from an experimental investigation for thin walled castings are shown in Fig. 2.

On the basis of a thermal analysis, the cooling rates near the equilibrium graphite eutectic solidification temperature were determined. Moulding materials with a low ability to absorb heat (e.g., LDASC sand) have a significant effect in reducing the cooling rates. ${ }^{24,25)}$ Attention should be paid to when LDASC sand is used as casting moulds (heat accumulation is equal $\left.a \approx 0.025 \mathrm{~J} /\left({ }^{\circ} \mathrm{C} \cdot \mathrm{cm}^{2} \cdot \mathrm{s}^{1 / 2}\right)\right)$ instead of silica sand (heat accumulation is equal $a \approx 0.10 \mathrm{~J} /\left({ }^{\circ} \mathrm{C} \cdot \mathrm{cm}^{2} \cdot \mathrm{s}^{1 / 2}\right)$ ), the cooling rates at the beginning of solidification decrease from about $29.1 \mathrm{~K} / \mathrm{s}$ to $5.8 \mathrm{~K} / \mathrm{s}$.

The influence of graphite morphology on the cooling curves is shown in the initial stage of the crystallization process (Fig. 2(b)). The undercooling that initializes solidification of eutectic in cast iron $\mathrm{V}$ is higher than in cast iron IV with a compacted graphite eutectic. It should be noted that, to obtain alloys IV and V the same amount of inoculant and vermicularizator were used. It is to ensure the same nucleation potential of the graphite from the point of view of the inoculation. Also in the case of thin-walled castings obtained in the mould based on silica sand, a higher value of the maximum undercooling at the beginning of the eutectic crystallization for a higher fraction of nodular graphite (Table 2) was recorded (Fig. 2(a)). In the case of the preparation of the cast iron with compacted graphite by a controlled amount of inoculant method, undercooling that initializes graphite eutectic solidification can be of the same order as in the case of ductile cast iron ${ }^{26)}$ or even lower. ${ }^{27,28)}$ Graphite eutectic growth in cast iron with flake graphite (cast iron VII, Fig. 2(b)) requires less driving force and thus eutectic undercooling is lower. On the cooling curve, it is shown that temperature of eutectic recalescence is much higher compared to those in SGI (Spheroidal Graphite Iron) and CGI. In this way, thermal analysis provides
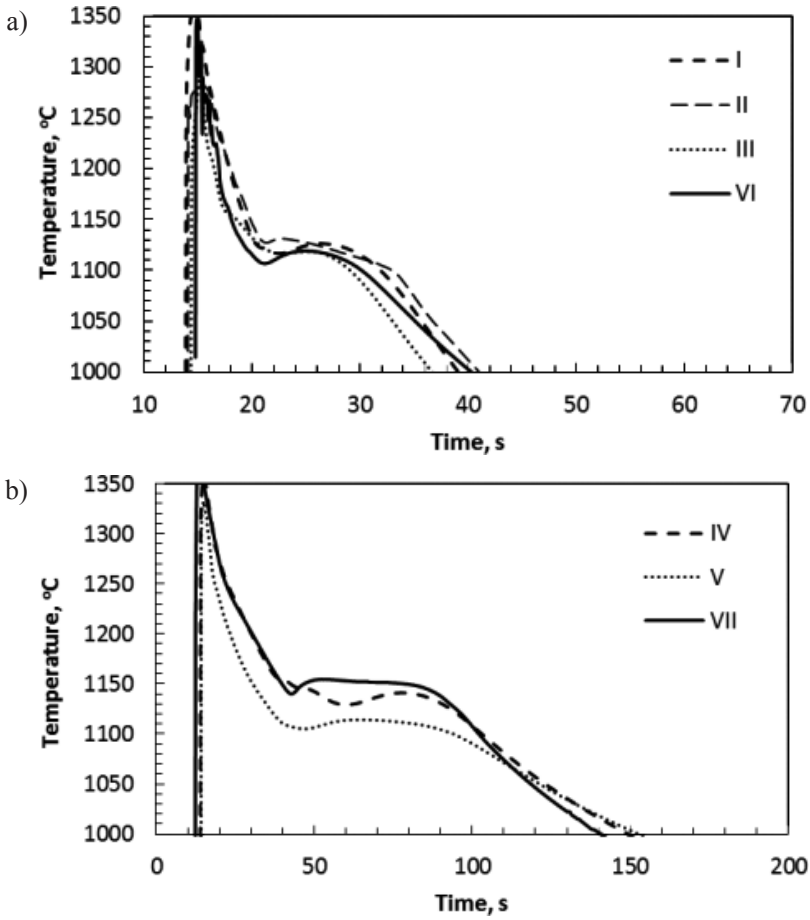

Fig. 2. Cooling curves for tested alloys: a) Alloys I, II, III and VI from silica foundry molds; b) Alloys IV, V and VII from LDASC foundry moulds.

the opportunity for foundry process control-from the view point of nucleation potential, chilling tendency and graphite morphology.

\subsection{As-cast Microstructure}

The results of metallographic analysis are shown in the Table 2. Figure 3 shows the exhibited microstructures found in thin walled castings from alloys I-VII.

Metallographic examinations revealed a significant effect of Ti additions on compacted graphite in thin walled castings. However, the addition of Ti requires the addition of extra magnesium to avoid any risks of graphite flake formation (see Fig. 3(b)). Thus, it is common to set a limit of $20 \%$ nodularity in order to meet CGI specifications. In the case of thin-walled castings, the natural tendency of CGI is to solidify with a higher nodularity in thin outer walls $(<4-5$ $\mathrm{mm}$ ) with up to $50 \%$ nodularity. Studies show that in TWCI castings with a wall thickness of $3 \mathrm{~mm}$, with an additions of $0.13 \%$ Ti result in reductions in the graphite nodule fraction from $97 \%$ for base iron (Alloy I), down to 34\% (Alloy III).

Metallographic evaluations clearly show that the use of LDASC insulation sand significantly reduces cooling rates (Fig. 2). In turn, this causes a significant increase in the compacted graphite fraction exhibited in the TWCI castings. When LDASC sands are employed in castings with wall thicknesses of $3 \mathrm{~mm}$, the compacted graphite fraction exceeds $65 \%$ (Fig. 3(e)). In the case of LDASC moulding sand and with the addition of titanium at the level of $0.13 \%$ in castings with wall thicknesses of $3 \mathrm{~mm}$, the compacted graphite fraction exceeds $80 \%$ (Fig. 3(d)). Thus, it satisfies the ISO Standard ${ }^{29)}$ concerning a minimum volume fraction of compacted graphite.

Eutectic cell (grain) is a product of spatial creation comprised of two or more interpenetrating crystals grow- 
ISIJ International, Vol. 55 (2015), No. 9

Table 2. Results of metallographic examinations.

\begin{tabular}{|c|c|c|c|c|c|c|c|}
\hline Alloy & Graphite type & $\begin{array}{l}\text { Graphite } \\
\text { fraction } \%\end{array}$ & $\begin{array}{l}\text { Graphite } \\
\text { nodule } \\
\text { fraction \% }\end{array}$ & $\begin{array}{c}\text { Ferrite } \\
\text { fraction, } f_{\mathrm{f}} \%\end{array}$ & $\begin{array}{l}\text { The maximum } \\
\text { length of the } \\
\text { graphite } \\
\text { particles }{ }^{*}, \mu \mathrm{m}\end{array}$ & $\begin{array}{c}\text { Shape factor }{ }^{* *} \\
\text { S }\end{array}$ & $\begin{array}{c}\text { Interparticle } \\
\text { distance } \\
l, \mu \mathrm{m}\end{array}$ \\
\hline I & Nodular & 15 & 97 & 37 & 10.84 & 0.81 & 65.9 \\
\hline II & Flake of D type & 20 & - & 70 & 15.12 & $<0.2$ & 3.3 \\
\hline III & Nodular + compacted & 13 & 34 & 30 & 58.29 & 0.67 & 72.5 \\
\hline IV & Nodular + compacted & 12 & 15 & 75 & 75.63 & 0.55 & 72.4 \\
\hline V & Nodular + compacted & 13 & 35 & 75 & 91.42 & 0.66 & 83.6 \\
\hline VI & Nodular + compacted & 14 & 73 & 67 & 49.11 & 0.76 & 67.8 \\
\hline VII & Flake of C type & 20 & - & 57 & 151.50 & 0.45 & 33.3 \\
\hline
\end{tabular}

* The maximum length of graphite particles were determined based on the average length of the five largest graphite particles in the measured field, and marked with no less than three parts of the polished section.

** Determination of the degree of compactness was based on the ratio of (S) defined as: ${ }^{30}$

$$
S=\frac{4 \pi A}{p^{2}}
$$

where:

$A$ - surface area occupied by graphite particles,

$\underset{* * * *}{p}$ - circumference of the graphite particles.

Interparticle distances were determined based on the Fullman equation. ${ }^{31)}$
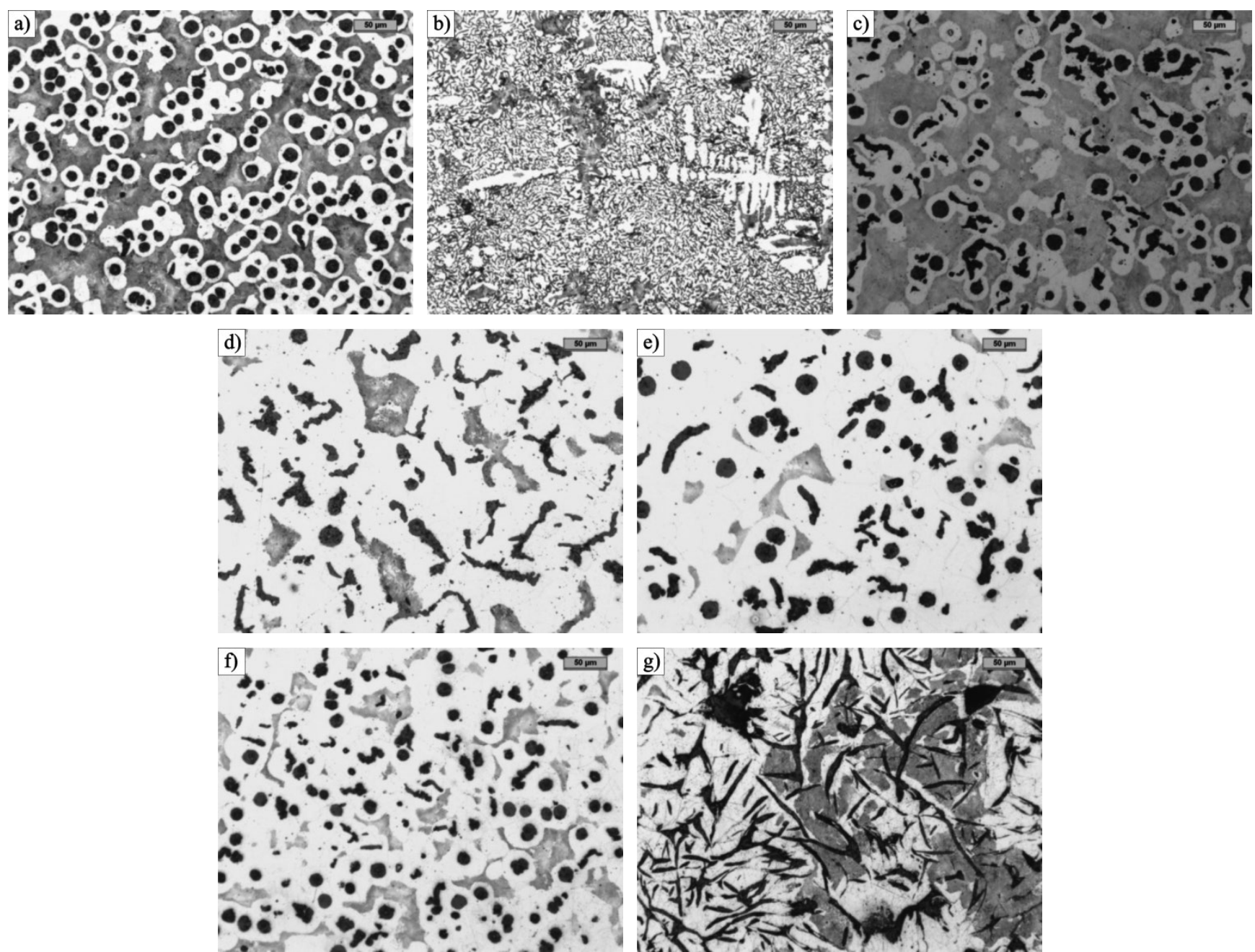

Fig. 3. Exhibited TWCI microstructures for castings with a wall thickness of $3 \mathrm{~mm}$ : (a) Alloy I, (b) Alloy II, (c) Alloy III, (d) Alloy IV, (e) Alloy V, (f) Alloy VI, (g) Alloy VII. Mag. 200x. Nital etchant used. 
ing from a single nucleus during eutectic transformation. Accordingly, each graphite nucleus is expected to give rise to a single graphite "worm" in compacted graphite cast iron. Compacted graphite particles appear to be vermicular when viewed in two dimensions (Fig. 3(d)), three dimension micrographs (after deep etching) show that individual compacted graphite ("worms") can be independent (Fig. 4(a)) or connected to their nearest neighbours within the eutectic cell (Fig. 4(b)). Due to graphite particle-austenite dendrite interactions, several graphite particles may be incorporated into one austenite grain.

\subsection{Thermal Conductivity}

The results of the influence of temperature on thermal diffusivity and specific heat are shown in Fig. 5 for different cast iron types. Figure 5(a) shows significant differences in thermal diffusivity at a temperature of $22^{\circ} \mathrm{C}$ and it becomes more similar at elevated temperatures. At a temperature of $22^{\circ} \mathrm{C}$, a difference of more than $6.4 \times 10^{-6} \mathrm{~m}^{2} / \mathrm{s}$ exists between cast iron with flake graphite type C (alloy VII) and ductile iron (alloy I).

Figure 5(b) shows that the value of the specific heat increases from $400 \mathrm{~J} /(\mathrm{kg} \cdot \mathrm{K})$ at temperature of $22^{\circ} \mathrm{C}$ up to $800 \mathrm{~J} /(\mathrm{kg} \cdot \mathrm{K})$ at a temperature of $600^{\circ} \mathrm{C}$. The difference of specific heat values between side points are similar throughout the temperature range and are about to equal $100 \mathrm{~J} /(\mathrm{kg} \cdot \mathrm{K})$. The results of cast iron thermal diffusivity and specific heat were then used in the calculation of the thermal
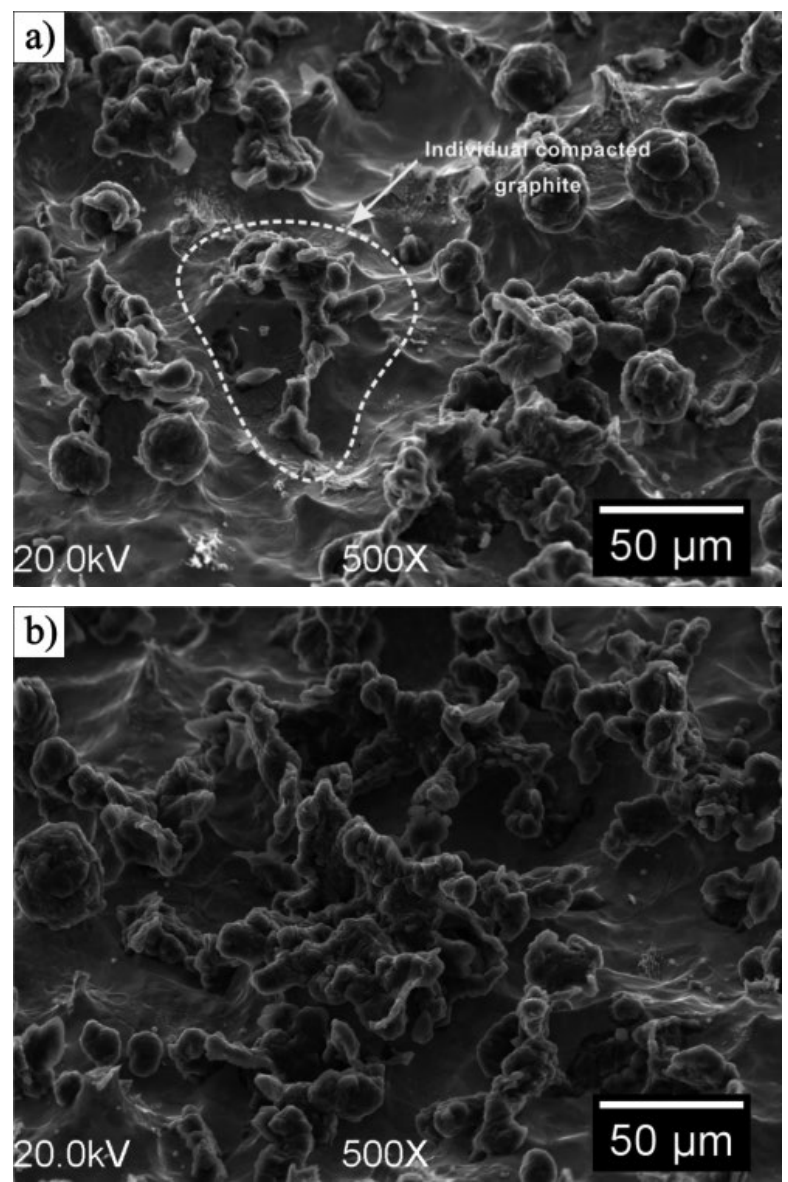

Fig. 4. Deep etched SEM microstructures showing individual compacted graphite (a) and highly branched compacted graphite (b). conductivity of the materials investigated in this study.

The results of thermal conductivity, calculated by Eq. (1), are shown in Fig. 6(a).

The highest value of thermal conductivity at room temperature, $46.8 \mathrm{~W} /(\mathrm{m} \cdot \mathrm{K})$ was achieved by alloy VII for gray iron with flake graphite type C. The lowest value, 15.9 $\mathrm{W} /(\mathrm{m} \cdot \mathrm{K})$, was attained by alloy I for ductile iron (reference alloy no I). Thus, a divergence of approximately 30 $\mathrm{W} /(\mathrm{m} \cdot \mathrm{K})$ at a temperature of $22^{\circ} \mathrm{C}$ was established, simply as a result of an alteration of cooling conditions and titanium additions.

In the case of cast iron in which flake graphite is both type $\mathrm{D}$ and $\mathrm{C}$, thermal conductivity decreases with a rise in temperature. This is due to the scattering of lattice vibrations (phonons) by defects in graphite, which become more pronounced with a rise in temperature. Flake graphite forms an interconnected network. The skeleton of a $\mathrm{C}$ type of eutectic structure exhibits a small number of crystallographic defects of graphite crystal and consequently, is poorly branched. On the other hand, the skeleton of a D type has a large number of crystallographic defects and is therefore much more branched. An important role is played by the shape factor for the effective conductivity of graphite in a metallic matrix. ${ }^{12)}$ It is two times smaller for $\mathrm{D}$ type graphite compared to those of $\mathrm{C}$ type graphite (Table 2). In the end, despite the smaller pearlite fraction in alloy II with D type graphite, the thermal conductivity is higher at temperatures up to $200^{\circ} \mathrm{C}$ for the alloy VII with $\mathrm{C}$ type graphite. From (a)

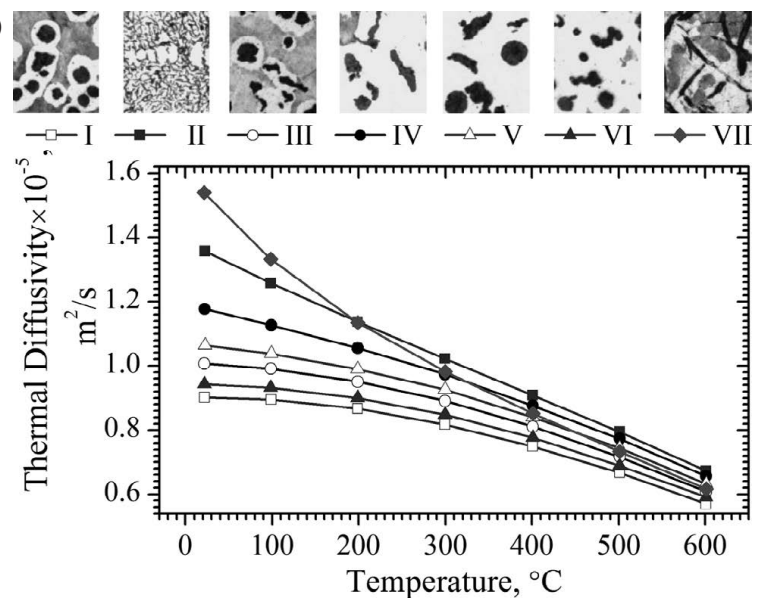

(b)
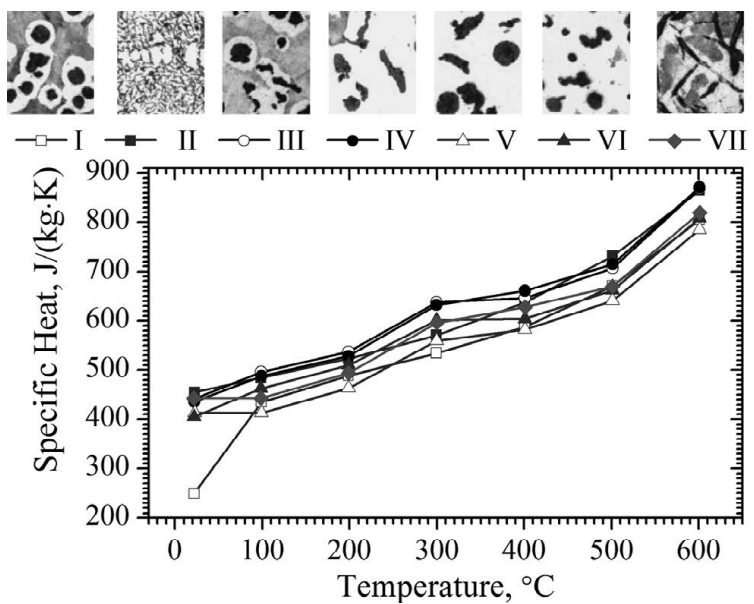

Fig. 5. Thermal diffusivity (a) and specific heat (b) for examined cast irons as a function of temperature. 
(a)
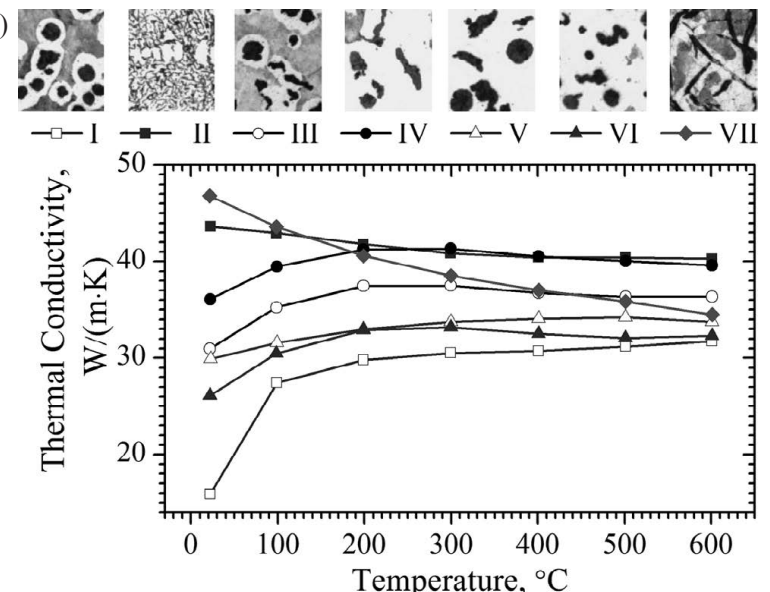

(b)

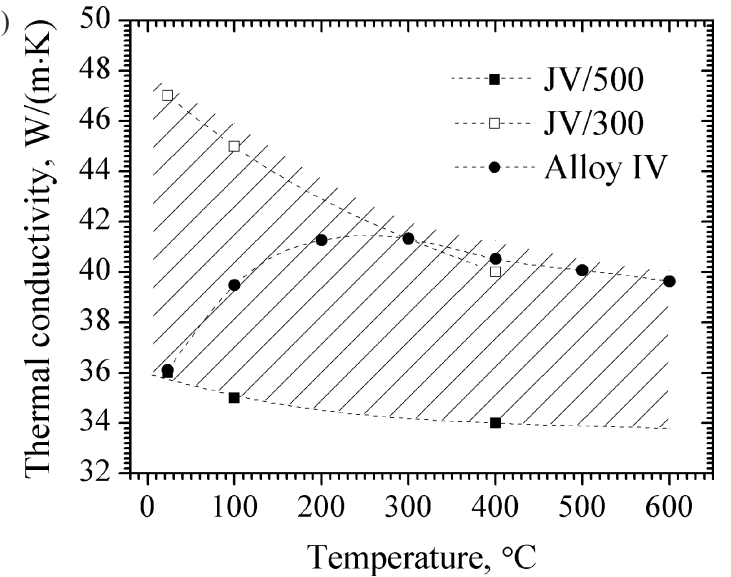

Fig. 6. Temperature dependence of thermal conductivity for examined cast irons (a), thermal conductivity of CGI obtained from experiment (Alloy IV) and ISO Standard ${ }^{29)}$ (where JV/300 and JV/500 represent grades of compacted graphite cast iron with minimum tensile strength of 300 $\mathrm{MPa}$ and $500 \mathrm{MPa}$, respectively) as a function of temperature (b).

a temperature of $200^{\circ} \mathrm{C}$, a higher thermal conductivity was obtained in gray cast iron with a D type flake graphite. This change may be associated with a significant reduction in the distance between the graphite particles (precipitate) (Table 2 ), and also with an increase of ferrite fraction in the microstructure. It should also be noted that the cast iron with flake graphite of type D (alloy no. II) shows much smaller differences in thermal conductivity with a temperature change in the range tested (Fig. 6(a)).

Thermal conductivity of iron matrix (which is a mixture of ferrite and pearlite) decreased with an increase in temperature. This is the normal behaviour of metallic materials. With an increase of temperature the amplitude of the oscillation of ions are also increases in the metal structure, and therefore increases the likelihood of collision of electrons with ions, thereby reducing the length of the mean free path. Interactions between electrons and phonons determine the final thermal conductivity in a metallic materials. Due to phonon interactions, thermal conductivity is expected to decrease with an increase in temperature. Alloying elements and the presence of pearlite in the iron matrix, results in a reduction in thermal conductivity as they act as scattering obstacles lowering the efficiency of electron motion. According to the ${ }^{27)}$ conductivity for pearlitic grades within the same temperature range, there is approximately twenty percent less in comparison to ferritic grades.

In the case of cast iron with compacted and nodular graphite, initially from ambient temperature up to a temperature of $200^{\circ} \mathrm{C}$, thermal conductivity increases with a rise in temperature. Further increase in temperature causes a slight change in thermal conductivity. This can be attributed to the graphite-matrix interface where thermal boundary resistance (thermal resistance is the reciprocal of thermal conductance) plays an important role in heat transportation phenomena preferably at a higher temperature. Roughness, shape and area of the interfacial boundary ${ }^{32)}$ influences the thermal boundary resistance between graphite and matrix.

With an increase in temperature, thermal boundary resistance rapidly decreases. ${ }^{33,34)}$ In this connection at lower temperatures (close to ambient temperature) the graphitematrix interface may have higher thermal resistance. At higher temperatures, the heat boundary resistance is lower and thus increases the heat transfer through graphite nodules or "worms" which explains the increases in thermal conductivity of cast iron with compacted or nodular graphite from ambient temperature up to a temperature of $200^{\circ} \mathrm{C}$.

As can be seen in Fig. 6(a) the difference in thermal conductivity between the examined cast irons decreases at elevated temperatures. Such a tendency of small differences between grey, ductile and compacted graphite iron at increasing temperatures, has been reported in work done $\mathrm{e}^{14)}$ for castings with a typical wall thickness.

The effect of the percentage of compacted graphite on thermal conductivity at different temperatures is also shown in Fig. 6(a). It is clear from this figure, that increasing the percentage of compacted graphite causes an increase in thermal conductivity. The presence of graphite nodules within the microstructure negatively affects the thermal conductivity of compacted graphite cast iron. It is worth noting that the thin-walled castings of alloy IV are characterized by high thermal conductivity at elevated temperatures (with an effect starting from $200^{\circ} \mathrm{C}$ ), which reaches the level of those obtained for the cast iron with flake graphite. As in the case of grey cast iron with D type flake graphite, compacted graphite cast iron (Alloy IV) shows little change in the thermal conductivity in the investigated temperature range, especially compared to ductile iron. This feature should be attributed primarily to short and thick compacted graphite with rounded edges (when compared to normal type A flake eutectic graphite) which are randomly oriented and can be connected to their nearest neighbours within an eutectic cell (as in grey cast iron). ${ }^{35)}$ Figure 6(b) showed values of thermal conductivity for cast iron with compacted graphite in accordance with the ISO 16112 Standard $^{29)}$ compared to the value of thermal conductivity of cast iron obtained for alloy IV. It can be concluded, that the obtained values of thermal conductivity in thin-walled castings with a wall thickness of $3 \mathrm{~mm}$ are within the limits prescribed for CGI. Furthermore, it can be added that the thin-walled compacted graphite cast iron can characterize good mechanical properties ${ }^{18)}$ and at the same time high thermophysical properties that predispose them to work in variable thermal loaded conditions. It is also a very important fact, that tool life is increased with higher thermal conductivity.

Summing up, TWCI provides an opportunity to meet 
the performance requirements of the next generation of engineered components, particularly castings exposed to variable thermally loaded conditions (cylinder blocks and heads). The current casting market is driving the need for stronger cast irons with lower total assembly weight than grey cast iron parts, but with improved machinability, thermal-fatigue resistance, damping capacity, casting mould yield, and castability compared to ductile iron parts. From the point of view of economics and ecology, TWCI can compete with aluminium alloy, providing unique mechanical and thermal properties and ensuring new opportunities to satisfy the requirements of lightweight thin-walled castings.

\section{Conclusions}

(1) The thin walled castings made of cast iron with compacted graphite have high thermal conductivity at an elevated temperature (from $200^{\circ} \mathrm{C}$ ), which achieve the level of those obtained for cast iron with flake graphite.

(2) Thin walled castings made of cast iron with compacted graphite similar to cast iron with type D flake graphite shows little change in the value of thermal conductivity in the investigated temperature range of $\left(22-600^{\circ} \mathrm{C}\right)$ in comparison, especially to ductile iron.

(3) Thin walled castings made of cast iron with compacted graphite have good mechanical properties ${ }^{18)}$ and simultaneously high thermophysical properties, which predispose them to work in variable thermally loaded conditions by minimizing the accumulation of thermally induced stress.

(4) The existence of spheroidal graphite within the microstructure negatively affects the thermal conductivity of compacted graphite cast iron in thin sections. It is manifested in the reduction of thermal conductivity as well as an increased sensitivity to change in variable thermally loaded conditions.

\section{Acknowledgements}

The authors acknowledge financial support from the Polish National Science Centre grant No. 2013/09/B/ ST8/00210.

\section{REFERENCES}

1) M. Okayasu and S. Yoshida: Int. J. Cast Met. Res., 28 (2015), 105.

2) J. Lelito, P. Żak, A. A. Shirzadi, A. L. Greer, W. K. Krajewski, J. S. Suchy, K. Haberl and P. Schumacher: Acta Mater., 60 (2012), 2950.

3) C. Zhou, D. Chen, X. B. Zhang, Z. Chen, S. Y. Zhong, Y. Wu, G. Ji and H. W. Wang: Phys. Lett. A, 379 (2015), 452.

4) H. Wu, C. Lu, W. Zhang and X. Zhang: Mater. Design, 52 (2013), 621.

5) D. M. Stefanescu and R. Ruxand: Proc. 65th World Foundry Cong., Korean Foundrymen's Society; Gyeongju, Korea, (2002).

6) E. Fraś, M. Górny and H. F. Lopez: Foundry Trade J., 185 (2011), 85.

7) E. Fraś, M. Górny, E. Tyrała and H. Lopez: Mater. Sci. Technol., 28 (2012), 1391.

8) W. Guesser, T. Schroeder and S. Dawson: AFS Trans., 109 (2001), 1.

9) S. Dawson: Mod. Cast., 88 (1998), 38

10) S. Dawson: China Foundry, 6 (2009), 241.

11) D. Holmgren, R. Kallbom and I. L. Svensson: Metall. Mater. Trans. A, 38 (2007), 268.

12) J. Helsing and G. Grimvall: J. Appl. Phys., 70 (1991), 1198.

13) M. C. Rukadikar and G. P. Reddy: J. Mater. Sci., 21 (1986), 4403.

14) D. Holmgren: Int. J. Cast Metall. Res., 18 (2005), 331.

15) R. Monroe and C. Bates: AFS Trans., 90 (1982), 615.

16) L. Hecht, R. B. Dinwiddie and H. Wang: Mater. Sci., 34 (1999), 4775.

17) M. Górny and M. Kawalec: J. Mater. Eng. Perform., 22 (2013), 1519.

18) M. Górny, M. Kawalec, G. Sikora and H. Lopez: ISIJ Int., 54 (2014), 2288.

19) J. Zhou: China Foundry, 8 (2011), 154.

20) I. Riposan, M. Chisamera, R. Kelley, M. Barstow and R. L. Naro: AFS Trans., 111 (2003), 869.

21) M. Holtzer, M. Górny and R. Dańko: Microstructure and Properties of Ductile Iron and Compacted Graphite Iron Castings-The Effects of Mold Sand/Metal Interface Phenomena, Springer, Cham, Heidelberg, New York, Dordrecht, London, (2015), 139.

22) M. Górny, R. Dańko and M. Holtze: Metalurgija, 54 (2015), 11.

$23)$ O. Erfan and O. Elmabrouk: Int. J. Eng. Innovative Technology, 3 (2014), 29.

24) R. E. Showman and R. C. Aufderheide: AFS Trans., 112 (2004), 823.

25) M. Górny and E. Tyrała: J. Mater. Eng. Perform., 22 (2013), 300.

26) L. Jinhai, Y. Litao, L. Guolu, L. Changqi, L. Yinguo and L. Y. Zhaoyu: China Foundry, 3 (2011), 295.

27) J. R. Davis: Cast Irons, ASM Specialty Handbook, ed. by ASM International Handbook Committee, OH, (2006), 80.

28) D. Stefanescu, F. Martinez and I. Chen: AFS Trans., 91 (1983), 205.

29) ISO 16112:2006, Compacted Graphite Cast Irons-Classification, ISO Standardization, ISO, Geneve, (2006).

30) S. Charoenvilaisiri, D. Stefanescu, R. Ruxanda and T. Piwonka: AFS Trans., 110 (2002), 1113.

31) R. L. Fullmann: Trans. AIME, 197 (1953), 447.

32) S. Merabia and K. Termentzidis: Phys. Rev. B, 89 (2014), 1.

33) H. Fenech and W. M. Rohseno: J. Heat Transf., 85 (1963), 15

34) J. Koráb, G. Korb, P. Stefánik and H. P. Degischer: Compos. Part A, 30 (1999), 1023.

35) M. Konig: Int. J. Cast Met. Res., 23 (2010), 185 